\title{
Yearly variation in the structure and diversity of a non-breeding passerine bird community in a Mediterranean wetland
}

\author{
Juan Arizaga*, Daniel Alonso, Ariñe Crespo, Xabier Esparza, Efrén Fernández, Iñigo López, David Martín \\ and Antonio Vilches
}

\begin{abstract}
Background: The dynamics and structure of many bird communities are changing due to the global warming and changes in the land use and management. The Ebro Valley constitutes one of the chief wintering areas for several passerine species in Iberia, and the reed beds spread across this Valley concentrate huge numbers of birds that use them to roost, while the surrounding agricultural areas serve as main foraging habitats. The aims of this work are (1) to quantify how variable a non-breeding passerine bird community associated to a reed bed area in the Ebro Valley is, and, (2) to test for the effect of weather on possible annual fluctuations in species' proportions at a regional/local scale.
\end{abstract}

Methods: We used for that ringing data collected at Badina de Escudera lagoon (Navarra) over a 12-year period.

Results: Though, overall, the assemblage did not vary strongly among years (most similarity values were >0.8), we still found a significant linear effect of year on the proportion of captures of Reed Buntings (Emberiza schoeniclus), i.e., the dominant species detected in our passerine community. The increasing loss of weight of Reed Buntings in the community was due to a progressive decrease in its abundance.

Conclusions: The structure and diversity of passerine community in Badina Escudera was not influenced by meteorological conditions at a local scale, suggesting that local weather would not have an impact on numbers of Reed Buntings in winter.

Keywords: Navarra, Emberiza schoeniclus, Ringing, Long-term monitoring

\section{Background}

Currently, the dynamics and structure of many bird communities are changing due to the global warming and changes in the land use and management. Many studies dealing with avian communities focus on comparisons between habitat types (Sisk et al. 1997; Paquet et al. 2006; Reis et al. 2012; Santos et al. 2014), between seasons through a given annual cycle (Purroy 1975; Herrera 1980; Arizaga et al. 2009b; 2010) or before and after a given

*Correspondence: jarizaga@aranzadi.eus

Department of Ornithology, Aranzadi Sciences Society, Zorroagagaina 11, 20014 S. Sebastián, Spain disturbance or management in a habitat (Barlow et al. 2002; Brotons et al. 2005). However, studies addressing how and why this structure varies temporally based on long-term analyses, are few (Sebastian-Gonzalez et al. 2010). Such long-term analyses are called to contribute to understand which factors shape variation at community level under global change contexts.

The Mediterranean region is an area of capital importance for the conservation of many migratory bird populations of northern Europe that either pass over southern Europe in the way to their wintering areas in Africa or choose the Mediterranean as their winter destination (Tellería et al. 1999). Evidence supports the idea that the 
communities of birds that spend the winter in the Mediterranean region are changing due to climate warming (Morganti and Pulido 2012). In particular, an increasing proportion of birds that would hypothetically overwinter in tropical Africa now stay all the winter in the southern part of the Mediterranean (Morganti and Pulido 2012); at the same time, many species that used to overwinter in the Mediterranean are moving their wintering range to higher latitudes and altitudes (Martín et al. 2014; Tellería et al. 2016; Podhrázský et al. 2017; Pavón-Jordán et al. 2019). Additionally, changes in the land use and management, e.g. under the European Common Agricultural Policy framework, can have a significant impact on bird populations (Donald et al. 2001; Bani et al. 2009), which might also have an effect at the assemblage level.

The Ebro Valley constitutes one of the chief wintering areas for several passerine species in Iberia (Tellería 1988). The reed beds spread across this Valley and concentrate huge numbers of birds that use them to roost, while the surrounding agricultural areas serve as main foraging habitats (Senar and Borras 2004). Reed Buntings (Emberiza schoeniclus) constitute a paradigmatic case of such agricultural-associated birds (Cramp and Perrins 1994). These reed beds, therefore, can be a good monitoring unit to test for the occurrence of temporal variations in bird communities, and to deepen into the factors driving the variation.

The aims of this work are (1) to quantify how variable a non-breeding passerine bird community associated to a reed bed area in the Ebro Valley is, and, (2) to test for the effect of weather on possible annual fluctuations in species' proportions at a regional/local scale. We used for that ringing data collected over a 12 -year period.

\section{Methods}

\section{Study area and data collection}

This study was carried out at the Badina Escudera lagoon $\left(42.27^{\circ} \mathrm{N}, 01.70^{\circ} \mathrm{W}, 281 \mathrm{~m}\right.$ above sea level), situated in Navarra, Ebro Valley, northern Iberia. The lagoon occupies ca. 160 ha, and it has been declared as a Natura 2000 site (SPA ES2200039, Badina Escudera).

During the winter season (from October to March) starting in October of 2003 to 2014 (12 years), ringing was carried out on a minimum of 15-days interval basis (i.e., twice a month), but due to different causes (mainly bad weather and logistics) this schedule was not always possible to be executed. Mist nets were open during a period of $2 \mathrm{~h}$ before dusk each sampling day. Target species were those that come from northern Europe to overwinter in Spain. The scheme was designed to sample the entire period of presence of these wintering birds in Spain, from passage/arrival in autumn to departure to breeding quarters in late-winter or spring (Tellería 1988;
Tellería et al. 1999; Arizaga et al. 2011). All captured birds were ringed, measured, and their age and sex determined (Svensson 1996), though these data were not used in this work.

Meteorological data were collected from the Caparroso meteorological station, located at just $10 \mathrm{~km}$ from Badina Escudera (source: AEMET). The data obtained from this station were: (1) monthly average of the daily means and minimum temperatures; (2) monthly accumulated precipitation.

\section{Data handling and statistics}

We considered for the analyses three temporal categories, that fitted with the phenological status of short-distance migrants at Badina (Arizaga et al. 2009b): Oct-Nov (passage/arrival of winter visitors), Dec-Jan (winter period), Feb-Mar (departure to breeding quarters/passage). Within each period and year only the first capture event of each individual bird was considered to remove pseudo-replicates.

First, we examined the structure of the bird community for each period, in order to identify the dominant species. Only those accounting for $>10 \%$ of the captures were considered to model trends thereafter. With that goal, we calculated the proportion of captures per species and period. After that, we conducted General Linear Models (GLM) with the proportion of captures as an object variable and the year, temperature and/or precipitation as covariates. For the meteorological variables we calculated the mean values for each period (i.e., Oct-Nov, Dec-Jan or Feb-Mar). For each period, we conducted a global (saturated) additive model, which was then submitted to a model selection procedure, for which the 'dredge' function of the package 'MuMIn' for R was used (Barton 2014; R Core Team 2014). Models differing in less than 2 Akaike values were considered to fit to the data equally well (Burnham and Anderson 1998). We also conducted GLM to analyse whether the standardized number of captures (captures/100 linear meters of mist nets) of those species which had major weight in the community had significant temporal trends.

Using this same filtered data set, we conducted a Hierarchical Analysis of Clusters in order to see the relationship among different years using the Morisita-Horn similarity index, which is very responsive to dominant taxa (Magurran and McGill 2011). This index was calculated as $\left[2 \times \Sigma\left(x_{i} y_{i}\right)\right] /\left[\left[\left(\sum x_{i}^{2} / X^{2}\right)+\left(\Sigma y_{i}^{2} / Y^{2}\right)\right] \times X Y\right]$, where $x_{i}$ is the number of times a given species $i$ is found in sample $X, y_{i}$ is the number of times a given species $i$ is found in sample $Y$, and $X$ and $Y$ are the number of species at samples $X$ and $Y$, respectively. The decision to select this index was based on our aim to quantify the role of 
inter-annual variations in the relative abundance of the most common species on bird assemblage structure. Clusters were built using the UPGMA method and the PAST software (Hammer et al. 2001).

Finally, we also assessed whether diversity indices varied annually and may also co-vary with weather-related variables. We also used the PAST software in order to calculate index of diversity (we used here the Shannon index, $H)$. The $H$ index is calculated as $-\Sigma\left(p_{i} \times \ln \left(p_{i}\right)\right)$, where $p_{i}$ was the proportion of captures of each species. Again, in this case we considered each individual bird only once per period and year. Using a bootstrapping approach, a $95 \%$ confidence interval associated to the yearly mean values was obtained and, therefore, it can be stated that overlapping confidence intervals reveal no (statistical) differences among years. Additionally, we conducted linear models in order to test for the effect of weather on diversity estimates. We used for that the program R (R Core Team 2014).

\section{Results}

In all of the three periods here studied, the community was dominated by Reed Buntings (with percentages of captures ranging between $54 \%$ and 68\%; Fig. 1). Except the Bearded Tit (Panurus biarmicus) in late winter, accounting for the $13.5 \%$ of captures, we found no other species that reached the $10 \%$ threshold of captures (Fig. 1). In winter (period Dec-Jan), the proportion of captures of trans-Saharan species ranged between zero to $0.5 \%$ (mean \pm SD: $0.1 \pm 0.2 \%$; Table 1$)$. These species were only present in three out of the eleven sampled winters (2006, 2008, 2012; Table 1), corresponding to three individual birds: a Water Pipit (Anthus spinoletta) in 2006 and 2008 (captures in 03 Dec 2006 and 28 Jan 2008), and a Willow Warbler (Phylloscopus trochilus) in 2012 (06 Dec 2012).

Overall, the proportion of Reed Buntings in any of the three temporal units considered tended to decrease along the study period (Fig. 2), at a mean rate of ca. $-4 \% /$ year (so a decrease of ca. $50 \%$ in 12 years).

Clustering analyses revealed, however, that, within each period, the structure of the assemblage was rather uniform across time, with overlaps of $>70 \%$ (often $>90 \%$ ) among years (Fig. 3). An exception to this pattern, however, arose in 2014, both during the period Oct-Nov and Feb-Mar (but not in mid-winter, i.e. period Dec-Jan). In 2014, the assemblage had a different structure, differing in $>50 \%$ in relation to the assemblages detected in previous years. A detailed look at this year, as compared to the mean values obtained up to then (2003-2013), revealed that during the period Oct-Nov in 2014 we captured a higher proportion of Reed Warblers (Acrocephalus scirpaceus) and Bluethroats (Luscinia svecica) and less Reed
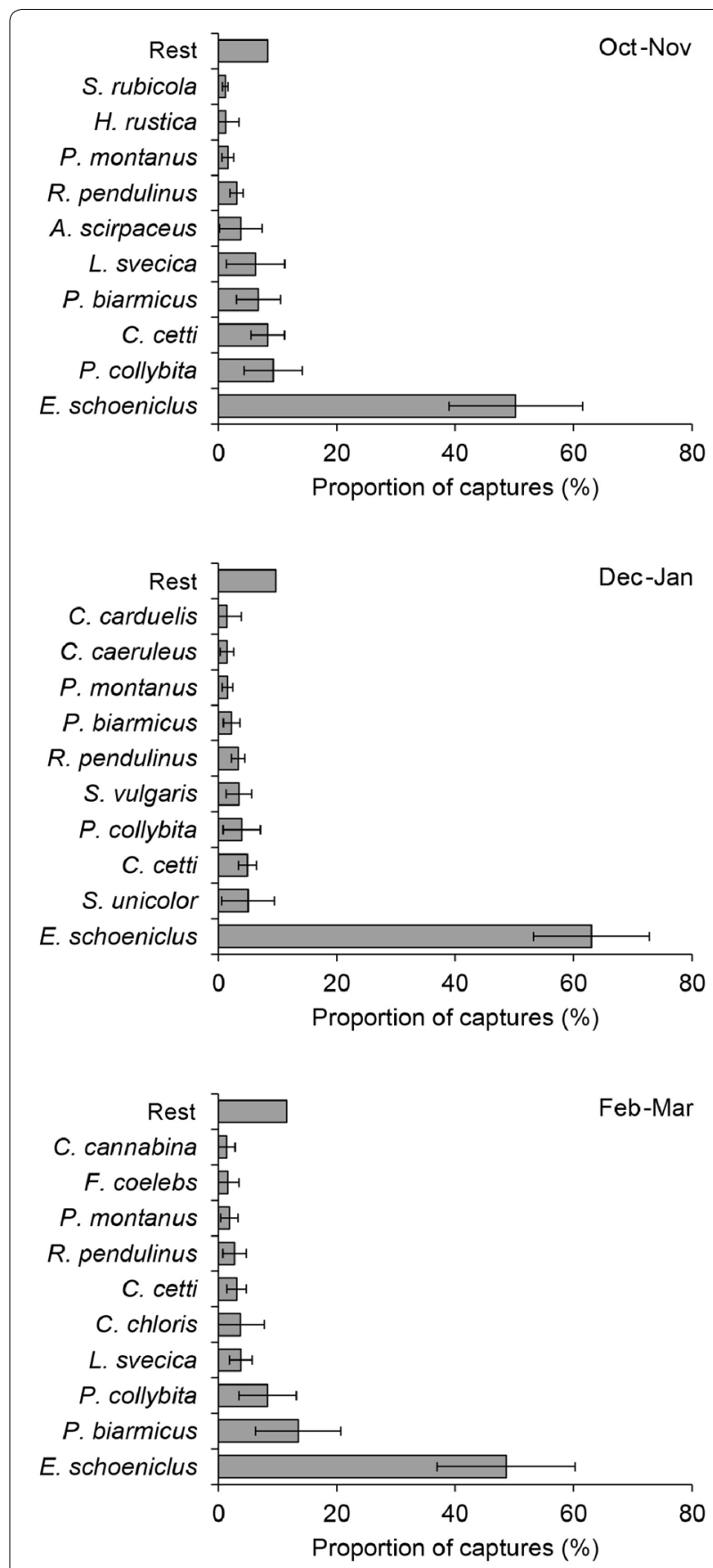

Fig. 1 Percentage of captures of the ten most abundant passerines captured with mist nets at Badina de Escudera, from 2003 to 2014

(a 12-year period; except for the period Dec-Jan, when no sampling was carried out in 2014). Within each period and year, each individual bird has been considered only once. Bars show the 95\% confidence interval

Buntings; during the period Feb-Mar in 2014, we captured a proportionally higher number of Green Finches (Chloris chloris) and Bearded Tits (Fig. 4). These results, 
Table 1 Tran-Saharan passerines captured during the winter period (Dec-Jan) in Badina de Escudera

\begin{tabular}{llll}
\hline Winter & $\boldsymbol{P}$ & $\boldsymbol{T}$ & $\boldsymbol{T} \%$ \\
\hline 2003 & 290 & 0 & 0 \\
2004 & 538 & 0 & 0 \\
2005 & 585 & 0 & 0 \\
2006 & 572 & 1 & 0.2 \\
2007 & 331 & 0 & 0 \\
2008 & 191 & 1 & 0.5 \\
2009 & 241 & 0 & 0 \\
2010 & 122 & 0 & 0 \\
2011 & 205 & 0 & 0 \\
2012 & 195 & 1 & 0.5 \\
2013 & 52 & 0 & 0 \\
\hline
\end{tabular}

The winter of 2003 corresponds to the one starting in December of 2003, and so on

$P$, number of captures of pre-Saharan passerines; $T$, number of captures of transSaharan passerines; $T \%$, percentage of captures of trans-Saharan passerines

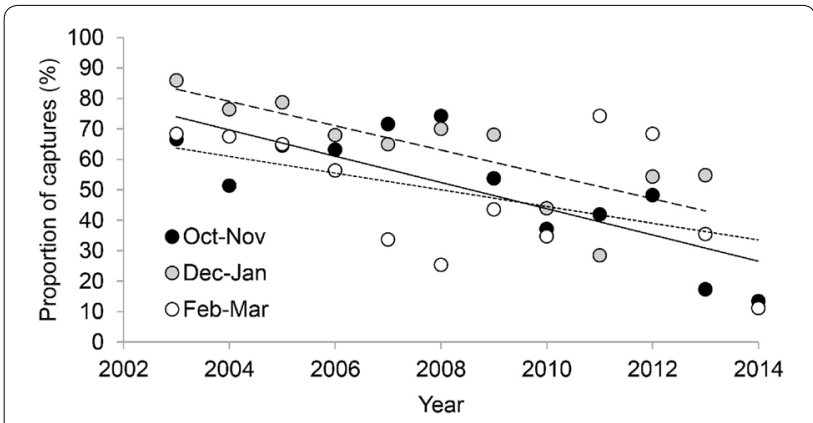

Fig. 2 Proportion of Reed Buntings captured in a passerines' assemblage at the reed bed of Badina Escudera (Navarra), during a period of 12 years ( 11 for the Dec-Jan period) however, could be biased by a decreasing sampling effort in 2014, when the lack of sampling in Feb and the existence of just one sampling day in Nov resulted in the loss of good periods of passage of Reed Buntings, hence their abundance might be under-represented (Additional file 1: Table S1).

Models showed that the proportion of Reed Buntings has declined dramatically from 2003 to 2014, both during the period Oct-Nov and Dec-Jan (i.e., during the autumn migration period and the wintering) (Table 2). None of the models that best fitted the data included weather effects (Additional file 1: Table S2) on Reed Buntings' proportion. If we remove 2014 for the reason shown above, we obtain results very similar to those shown in Table 2 (new table not included), especially for the negative effect of year on the proportion of captures of Reed Buntings. Furthermore, we also detected that the standardized number of captures of Reed Buntings tended to decrease along the study period, with this trend being significant for the Dec-Jan period (Fig. 5; slopes' significance: Oct-Nov, $t=0.157, P=0.875 ;$ Dec-Jan, $t=2.904, P=0.005$; Feb-Mar, $t=0.379, P=0.706$ ).

The diversity index differed markedly among years (Fig. 6). Overall, we detected a significant, positive trend for the first period (Oct-Nov: adjusted $R^{2}=0.46$, $P=0.008$ ), a marginal trend for the Dec-Jan period $\left(R^{2}=0.28, P=0.054\right)$, and a non-significant trend for the third period (Feb-Mar: $R^{2}=0.10, P=0.920$ ).

\section{Discussion}

The structure of a wintering passerine community in Badina Escudera, one of the main wetlands from Navarra (Ebro Valley) changed during the period of 12 years in which the study was done. Though, overall, the

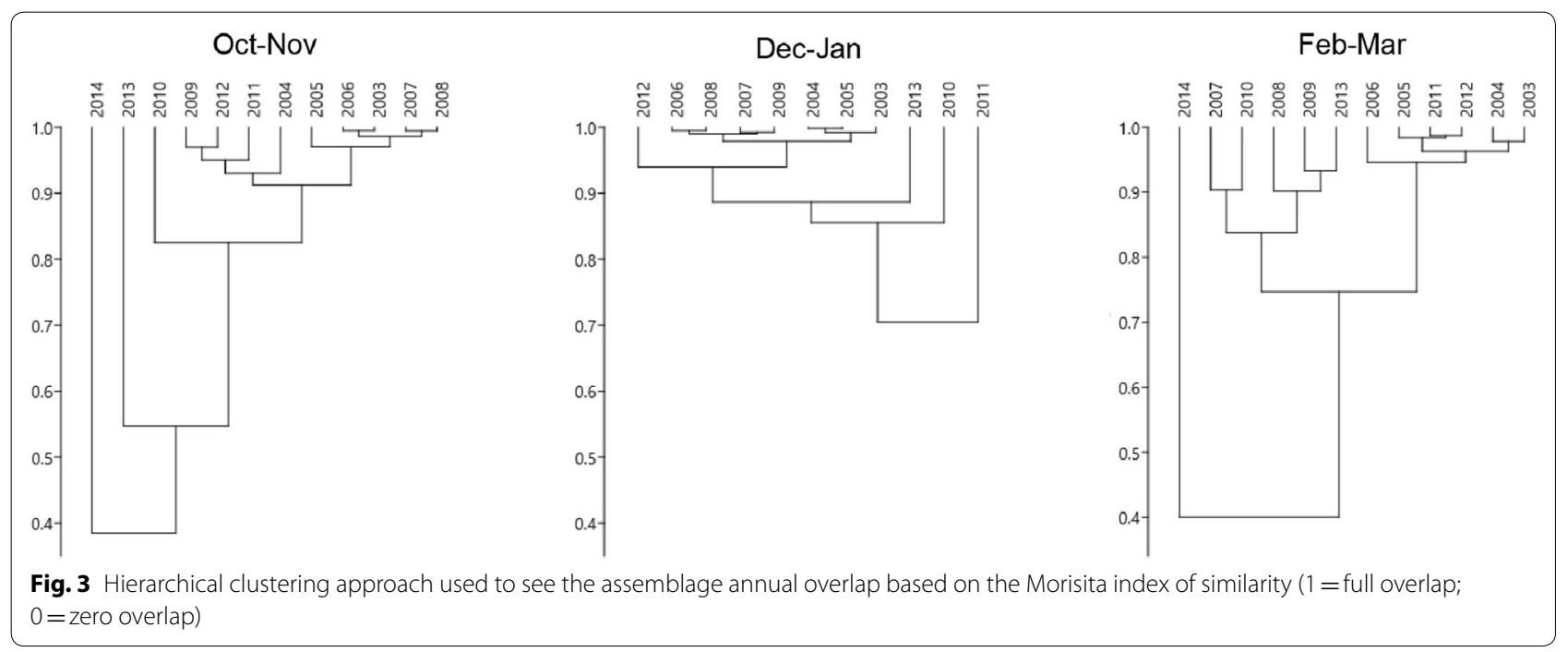




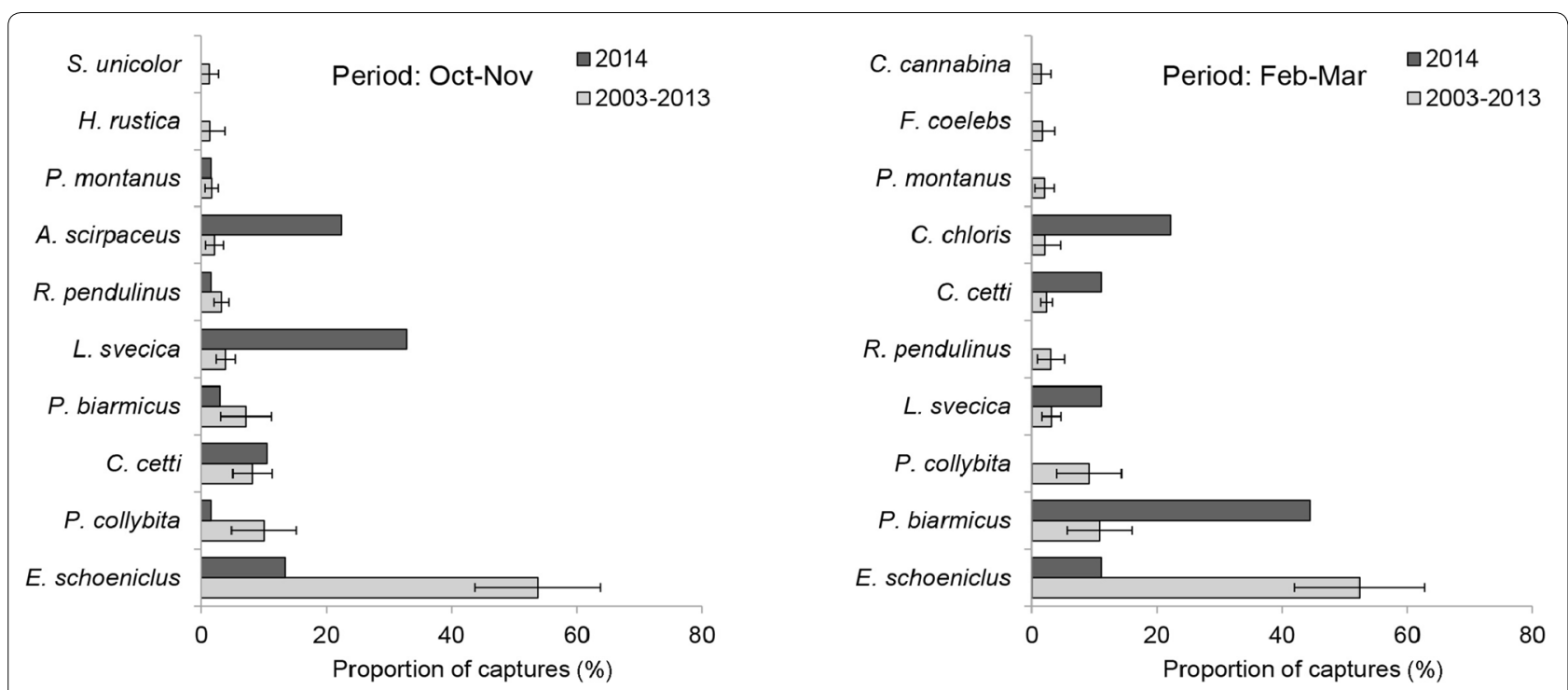

Fig. 4 Relative abundance of the ten most captured passerines at Badina Escudera during the period 2003-2013 (mean $\pm 95 \%$ confidence interval) as compared to 2014

Table 2 Best-ranked models used to test for the effect of local meteorological conditions on the proportion of captures of Reed Buntings

\begin{tabular}{lccc}
\hline Models & AICc & DAICc & AICc weight \\
\hline Period: Oct-Nov. & & & \\
1. Year & 102.5 & 0.0 & 0.596 \\
2. Year + $T_{\text {mean }}$ & 105.7 & 3.2 & 0.122 \\
Global & 119.6 & 17.1 & 0.000 \\
Period: Dec-Jan. & & & \\
1. Year & 90.2 & 0.0 & 0.724 \\
2. Year+Prec & 93.9 & 6.7 & 0.115 \\
Global & 109.4 & 19.2 & 0.000 \\
Period: Feb-Mar. & & & \\
1. Null & 111.0 & 0.0 & 0.293 \\
2. Year & 111.5 & 0.5 & 0.223 \\
3. Tmin & 111.6 & 0.6 & 0.210 \\
Global & 128.2 & 17.2 & 0.000 \\
\hline
\end{tabular}

Within each period, we show the list of models up to the first one with a $\Delta \mathrm{AIC}>2$, and the global (saturated) model

Year, linear effect of year; $T_{\text {mean }}$ mean temperature; $T_{\text {min' }}$ minimum temperature; Prec, precipitation; Null; null model with a constant intercept; AICc, small-sample size corrected Akaike values; $\triangle \mathrm{AICC}$, difference in relation to the Akaike value of the first model

assemblage did not vary strongly among years (most similarity values were $>0.8$; Fig. 3), we still found a significant linear effect of year in the proportion of captures of Reed Buntings, i.e., the dominant species detected in our passerine community. The analyses of avian communities often rely on data sets where long-term trends are rarely

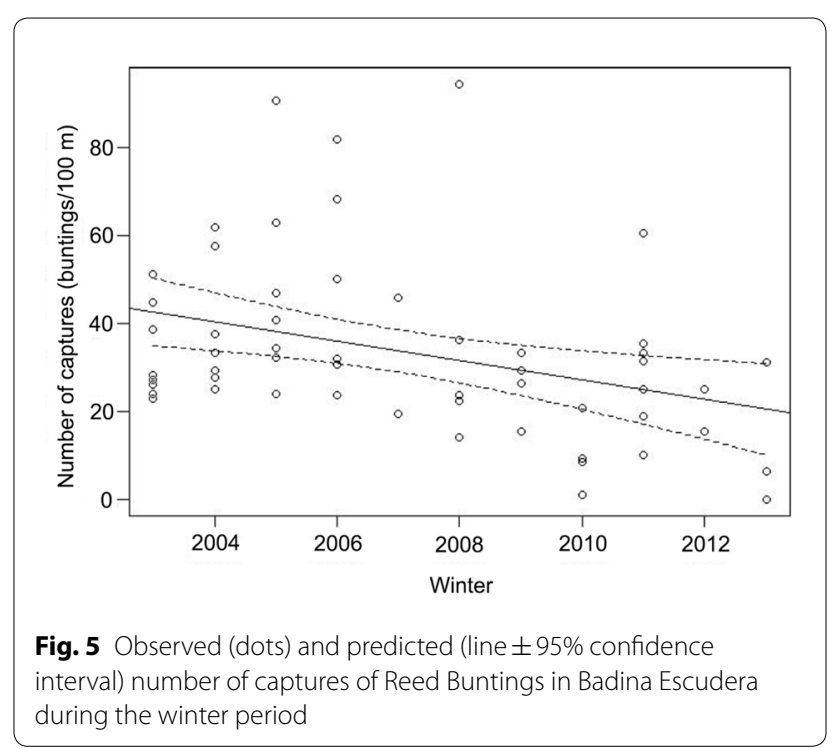

targeted. Our study is hence one of the few addressing such a question in a passerine community in Spain (Peiró 2018).

The increasing loss of weight of Reed Buntings in the community was likely due to a progressive decrease in the abundance of this species. Thus, in the mid-winter period, we passed from a mean number of 33.4 captures/100 linear meters of mist nets during the winter of 2003 to 12.4 captures/100 linear meters in 2014. The trend for the whole country remains uncertain (SEO/BirdLife 2012), but in some regions like Cataluña a decrease of 

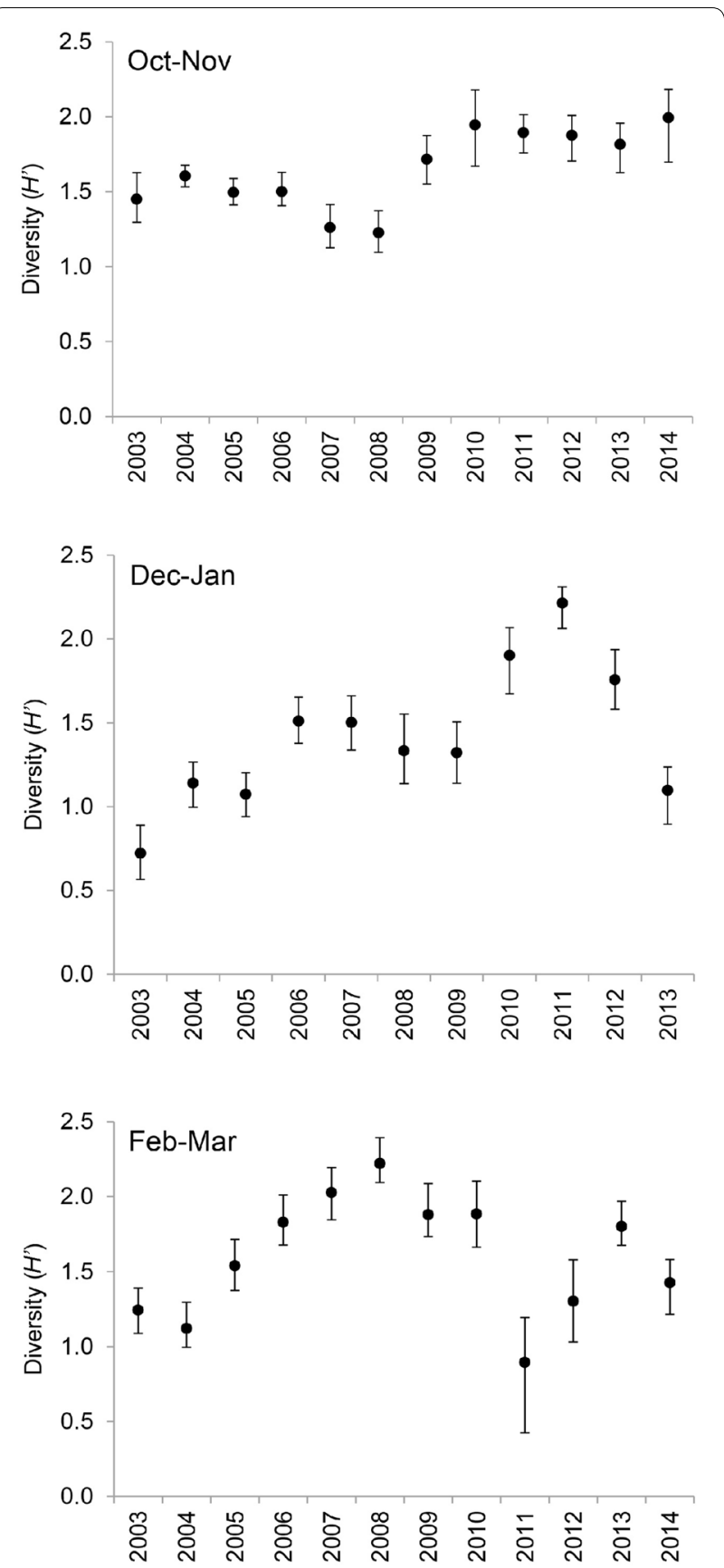

Fig. 6 Inter-annual variation of diversity $\left(H^{\prime}\right.$ index, $\pm 95 \%$ confidence interval)

$5 \%$ is estimated (Herrando et al. 2011). In Navarra, this decrease in the abundance may be due to several reasons: (1) habitat changes that may promote the spread and/or disappearance of Reed Buntings across/from the region, and (2) population declines. Though Badina and the nearby surrounding cropland did not suffer a remarkable change during the period in which the study was carried out (J. Arizaga obs. per.), we must notice habitat changes at a regional scale. The area occupied by the wet cultivations in the region has passed from $<76,000$ ha in 2002 to 84,000 in $2010(+10.5 \%)$, a trend that still is increasing (source: Government of Navarra). In parallel to this process, new ponds and ditches were created, and new reed beds (with potential to host Reed Buntings' roosts) were formed, which overall might have contributed to the dispersal of the species and reduction of Reed Bunting numbers in the old, 'traditional' roosts existing in wetlands such as Badina Escudera. A decrease of Reed Buntings arriving to overwinter in Spain is also plausible. This may be shaped by two processes: the fact that the species may overwinter in regions further to the north, which may be associated with the climate warming (Golawski and Kasprzykowski 2010; Martín et al. 2014; Pavón-Jordán et al. 2019; Wuczyński and Wuczyński 2019), and/or the consequence of real population declines. Following this last idea, it is seen that the Reed Bunting is in decline in Europe (Staneva and Burfield 2017), as is also declining in some of origin areas of birds that overwinter in Spain (Villarán 1999), more particularly in Badina Escudera (Arizaga et al. 2009b), such as France (Issa and Muller 2015) or Germany (Gedeon et al. 2015). And additional hypothesis associated with the decreasing of numbers of Reed Buntings in the area may be due to competition with other species which could be benefited by the climate warming and/or other processes of environmental change.

Weather is one of the capital factors shaping the spatio-temporal geographic distribution of bird populations (Elkins 1983; Cresswell 2014; Haest et al. 2018, 2019). However, the structure and diversity of passerine community in Badina Escudera was not influenced by meteorological conditions at a local scale. In another study carried out in a wetland in central Spain, researchers did not find that the inter-annual survival of Reed Buntings was affected by local temperature hence suggesting a lack of (significant) effect of winter temperature on this species' demography at a local level (Mezquida and Villarán 2006). However, winter severity in Spain correlated with apparent annual survival of Reed Buntings breeding in Germany (Salewski et al. 2013), hence it seems that meteorological conditions during the winter have an impact on Reed Buntings' demography. If the weather affects the geographic distribution of Reed Buntings in winter, it is likely that such distribution is modulated by climatic conditions operating at larger scales.

The presence of trans-Saharan passerines in winter was totally marginal through the entire study period (mean, $0.1 \%$ ). Such results suggest that the presence of these long-distance migrants in winter was still low in the studied wetland, as it seems to be also the case 
in other nearby sites within the region (Arizaga et al. 2009a; Mazuelas et al. 2018). This contrasts with the scenario already existing in southern Iberia, remarkably within the lowlands of the Guadalquivir Valley, where there is an increasingly high number of wintering trans-Saharan birds, both passerines and non-passerines (Morganti and Pulido 2012). Due to its geographic position in northern Iberia, the Ebro Valley is called to play a role as a sentinel region to document a potential geographical northward spread of trans-Saharan species in winter.

\section{Conclusions}

In conclusion, we detected that a non-breeding passerine bird community in a Mediterranean wetland in northern Spain varied during a period of 12 years. Reed Buntings were dominant, but their proportion and abundance tended to decrease across this period, especially if we focus on the mid-winter period. We did not find evidence supporting that local weather would have an impact on Reed Buntings' proportion. Ultimate causes underlying our findings may be related to both/either habitat changes and climate warming.

\section{Supplementary information}

Supplementary information accompanies this paper at https://doi. org/10.1186/s40657-020-00215-8.

Additional file 1: Table S1. Number of sampling days, per month and year, at Badina Escudera. Table S2. Mean values of the mean and minimum temperature and accumulated precipitation ( $T_{\text {mean }}, T_{\text {min }}$ Prec, as in Table 2) at Badina de Escudera, during the three time units considered in this study.

\section{Acknowledgements}

C. Astrain, J. M. Vadillo, and three reviewers provided valuable comments that helped us during the writing process of this work.

\section{Authors' contributions}

Conception: JA, DA. Data collection: JA, DA, AC, XE, EF, IL, DM, AV. Data analysis: JA, DA, AC. Writing: JA. Revision of the work: DA, AC, XE, EF, IL, DM, AV. All co-authors have approved the submission and agreed both to be personally accountable for the author's own contributions and to ensure that questions related to the accuracy or integrity of any part of the work, even ones in which the author was not personally involved, are appropriately investigated, resolved, and the resolution documented in the literature. All authors read and approved the final manuscript.

\section{Funding}

The analyses of the data set used in this work were funded by project LINDUS 2 (Interreg POCTEFA; European Regional Development Fund, ERDF) and the Government of Navarra, and with the support of GAN-NIK, S.A.

\section{Availability of data and materials}

The data that support the findings of this study are available from the Aranzadi Ringing Scheme but restrictions apply to the availability of these data, which were used under license for the current study, and so are not publicly available. Data are however available from the authors upon reasonable request and with permission of the Aranzadi Ringing Scheme.
Ethics approval and consent to participate

The Government of Navarra provided the licenses for bird ringing.

Consent for publication

Not applicable.

\section{Competing interests}

The authors declare that they have no competing interests.

Received: 22 January 2020 Accepted: 1 August 2020

Published online: 06 August 2020

\section{References}

Arizaga J, Alcalde JT, Alonso D, Bidegain I, Berasategui G, Deán Jl, et al. La laguna de Loza: flora y fauna de vertebrados. Munibe Suplemento 30. Donostia, Spain: Aranzadi. 2009a.

Arizaga J, Alonso D, Fernández E, Fernández I, Martín D, Vilches A. La laguna de Badina de Escudera (Navarra): características de la comunidad de aves paseriformes. Munibe Suplemento 28. Donostia, Spain: Aranzadi. 2009b.

Arizaga J, Alonso D, Fernández E, Martín D. Population structure of migrating and wintering reed buntings Emberiza schoeniclus in Northern Iberia. Ardeola. 2011:58:287-301

Arizaga J, Mendiburu A, Aranguren I, Asenjo I, Cuadrado JE, Díez E, et al. Estructura y evolución de la comunidad de paseriformes a lo largo del ciclo anual en el Parque Ecológico de Plaiaundi (marismas de Txingudi, Guipúzcoa). Ecología. 2010;23:153-64.

Bani L, Massimino D, Orioli V, Bottoni L, Massa R. Assessment of population trends of common breeding birds in Lombardy, Northern Italy, 1992-2007. Ethol Ecol Evol. 2009;21:27-44.

Barlow J, Haugaasen T, Peres CA. Effects of ground fires on understorey bird assemblages in Amazonian forests. Biol Conserv. 2002;105:157-69.

Barton K. MuMIn: Multi-model inference. R package version 1.10.5. Vienna, Austria. 2014. http://CRAN.R-project.org/package=MuMIn

Brotons L, Pons P, Herrando S. Colonization of dynamic Mediterranean landscapes: where do birds come from after fire? J Biogeogr. 2005;32:789-98.

Burnham KP, Anderson DR. Model selection and inference. A practical information theoretic approach. New York: Springer-Verlag; 1998.

Cramp S, Perrins CM. Handbook of the birds of Europe, the Middle East and North Africa, vol. 9. Oxford: Oxford University Press; 1994.

Cresswell W. Migratory connectivity of Palaearctic-African migratory birds and their responses to environmental change: the serial residency hypothesis. Ibis. 2014:156:493-510.

Donald PF, Green RE, Heath MF. Agricultural intensification and the collapse of Europe's farmland bird populations. P Roy Soc Lond B-Biol Sci. 2001;268:25-9.

Elkins N. Weather and bird behaviour. London: Poyser; 1983.

Gedeon K, Grüneberg C, Mitschke A, Sudfeldt C, Eickhorst W, Fischer S, et al. Atlas Deutscher Brutvogelarten. Berlin: Dachverband Deutscher Avifaunisten; 2015.

Golawski A, Kasprzykowski Z. The influence of weather on birds wintering in the farmlands of eastern Poland. Ornis Fennica. 2010;87:153-9.

Haest B, Hüppop O, Bairlein F. The influence of weather on avian spring migration phenology: What, where and when? Glob Change Biol. 2018;24:5769-88.

Haest B, Hüppop O, van de Pol M, Bairlein F. Autumn bird migration phenology: a potpourri of wind, precipitation and temperature effects. Glob Change Biol. 2019;25:4064-80.

Hammer $\varnothing$, Harper DAT, Ryan PD. PAST: palaeontological Statistics software package for education and data analysis. Palaeontol Electron. 2001;4:1-9.

Herrando S, Brotons L, Estrada J, Guallar S, Anton M. Atles dels ocells de Catalunya a I'hivern 2006-2009. Barcelona: ICO/Lynx; 2011.

Herrera CM. Evolución estacional de las comunidades de passeriformes en dos encinares de Andalucía Occidental. Ardeola. 1980;25:143-80.

Issa N, Muller Y. Atlas des oiseaux de France métropolitaine. Nidification et présence hivernale. Paris: LPO/SEOF/MNHN; 2015.

Magurran AE, McGill BJ. Biological diversity - frontiers in measurement and assessment. Oxford: Oxford University Press; 2011.

Martín B, Onrubia A, Ferrer MA. Effects of climate change on the migratory behavior of the common buzzard Buteo buteo. Clim Res. 2014;60:187-97. 
Mazuelas D, Gutiérrez Ó, Llorente S, Roncero L. Comunidad de paseriformes invernantes en un humedal del Valle del Ebro: el carrizal de Cofín, La Rioja (España). Zubia. 2018;36:163-77.

Mezquida ET, Villarán A. Abundance variations, survival and site fidelity of Reed Buntings Emberiza schoeniclus wintering in central Spain. Ornis Fennica. 2006;83:11-9.

Morganti M, Pulido F. Invernada de aves migradoras transaharianas en España. In: SEO/BirdLife, editor. Atlas de las aves en invierno en España 2007-2010. Madrid: Ministerio de Agricultura, Alimentación y Medioambiente-SEO/BirdLife; 2012. p. 59-64.

Paquet J-Y, Vandevyvre $X$, Delahaye L, Rondeux J. Bird assemblages in a mixed woodland-farmland landscape: the conservation value of silviculturedependant open areas in plantation forest. Forest Ecol Manage. 2006:227:59-70.

Pavón-Jordán D, Clausen P, Dagys M, Devos K, Encarnaçao V, Fox AD, et al. Habitat- and species-mediated short- and long-term distributional changes in waterbird abundance linked to variation in European winter weather. Divers Distrib. 2019;25:225-39.

Peiró I. The biodiversity of small passerine birds at wetlands: species loss and effects of climate change. Biodivers Int J. 2018;2:297-301.

Podhrázský M, Musil P, Musilová Z, Zouhar J, Adam M, Závora J, et al. Central European Greylag Geese Anser anser show a shortening of migration distance and earlier spring arrival over 60 years. Ibis. 2017;159:352-65.

Purroy FJ. Evolución anual de la avifauna en un bosque mixto de frondosas y coníferas en Navarra. Ardeola. 1975;21:669-97.

R Core Team. R: A language and environment for statistical computing. Vienna, Austria. 2014. http://www.R-project.org.

Reis E, López-lborra GM, Pinheiro RT. Changes in bird species richness through different levels of urbanization: implications for biodiversity conservation and garden design in Central Brazil. Landscape Urban Plan. 2012;107:31-42.

Salewski V, Hochachka WM, Fiedler W. Multiple weather factors affect apparent survival of European passerine birds. PLOS ONE. 2013;8:e59110.
Santos T, Carbonell R, Galarza A, Pérez-Tris J, Ramírez A, Tellería JL. The importance of northern Spanish farmland for wintering migratory passerines: a quantitative assessment. Bird Conserv Int. 2014;24:1-16.

Sebastian-Gonzalez E, Botella F, Paracuellos M, Sanchez-Zapata JA. Processes driving temporal dynamics in the nested pattern of waterbird communities. Acta Oecol Int J Ecol. 2010;36:160-5.

Senar JC, Borras A. Sobrevivir al invierno: estrategias de las aves invernantes en la Península Ibérica. Ardeola. 2004;51:133-68.

SEO/BirdLife. Atlas de las aves en invierno en España 2007-2010. Madrid: Ministerio de Agricultura, Alimentación y Medio Ambiente-SEO/BirdLife; 2012.

Sisk TD, Haddad NM, Ehrlich PR. Bird assemblages in patchy woodlands: modeling the effects of edge and matrix habitats. Ecol Appl. 1997;7:1170-80.

Staneva A, Burfield I. European birds of conservation concern: populations, trends and national responsibilities. Cambridge: BirdLife International; 2017

Svensson L. Guía para la identificación de los paseriformes europeos. Madrid: Sociedad Española de Ornitología; 1996.

Tellería JL. Invernada de aves en la Península Ibérica. Madrid: SEO/BirdLife; 1988.

Tellería JL, Asensio B, Díaz M. Aves Ibéricas. II. Paseriformes. Madrid: JM Reyero Edn; 1999.

Tellería JL, Fernández-López J, Fandos G. Effect of climate change on mediterranean winter ranges of two migratory passerines. PLOS ONE. 2016;11:e0146958.

Villarán A. Migración e invernada del escribano palustre (Emberiza schoeniclus) en España. Ardeola. 1999:46:71-80.

Wuczyński A, Wuczyński M. Birds wintering in heterogeneous farmland of Poland: weather-dependent temporal changes in abundance and habitat associations. Acta Ornithol. 2019;54:105-24.
Ready to submit your research? Choose BMC and benefit from:

- fast, convenient online submission

- thorough peer review by experienced researchers in your field

- rapid publication on acceptance

- support for research data, including large and complex data types

- gold Open Access which fosters wider collaboration and increased citations

- maximum visibility for your research: over $100 \mathrm{M}$ website views per year

At BMC, research is always in progress.

Learn more biomedcentral.com/submissions 